\title{
Helène Gallé, Héros et comparses. La valeur morale des Bourguignons dans la chanson de geste
}

\author{
Maria Colombo Timelli
}

\section{(2) OpenEdition}

1 Journals

\section{Édition électronique}

URL : http://journals.openedition.org/studifrancesi/9752

DOI : ERREUR PDO dans /localdata/www-bin/Core/Core/Db/Db.class.php L.34 : SQLSTATE[HY000]

[2006] MySQL server has gone away

ISSN : 2427-5856

\section{Éditeur}

Rosenberg \& Sellier

Édition imprimée

Date de publication : 1 octobre 2007

Pagination : 412

ISSN : 0039-2944

\section{Référence électronique}

Maria Colombo Timelli, «Helène Gallé, Héros et comparses. La valeur morale des Bourguignons dans la chanson de geste », Studi Francesi [En ligne], 152 (LI | II) | 2007, mis en ligne le 30 novembre 2015, consulté le 07 janvier 2021. URL : http://journals.openedition.org/studifrancesi/9752 ; DOI : https:// doi.org/ERREUR PDO dans /localdata/www-bin/Core/Core/Db/Db.class.php L.34 : SQLSTATE[HY000] [2006] MySQL server has gone away

Ce document a été généré automatiquement le 7 janvier 2021.

\section{(c)}

Studi Francesi è distribuita con Licenza Creative Commons Attribuzione - Non commerciale - Non opere derivate 4.0 Internazionale. 


\section{Helène Gallé, Héros et comparses. La valeur morale des Bourguignons dans la chanson de geste}

Maria Colombo Timelli

\section{RÉFÉRENCE}

HELÈNE GALLÉ, Héros et comparses. La valeur morale des Bourguignons dans la chanson de geste, in L'épopée médiévale et la Bourgogne (sous la dir. de Muriel Ott), Dijon, EUD, 2006, pp.

13-32.

Dans les chansons de geste, les Bourguignons sont nombreux: cependant, avec l'exception remarquable de Girart de Roussillon, il s'agit pour la plupart de personnages non typisés, qui peuvent par conséquent être utilisés comme des «personnages à tout faire» (p. 32), des comparses qui disparaissent du récit une fois leur rôle terminé. H.G. peut en conclure qu'une 'identité bourguignonne' n'existe de fait pas dans les textes épiques. 